\title{
Chronic cadmium poisoning in a pigment manufacturing plant
}

\author{
P E DE SILVA AND M B DONNAN \\ From the Industrial Hygiene Section, Health Commission of Victoria, Melbourne, Australia
}

\begin{abstract}
When the working environment in a small cadmium-pigment manufacturing plant was investigated cadmium concentrations in respirable dust were found to be considerably above the hygiene standard recommended by the British Occupational Hygiene Society. Cadmium concentrations in blood and urine of exposed workers, both present and past employees, were determined. The six men who had worked in the production plant for seven years or more all showed signs of renal tubular damage. In addition two of these men exhibited exertional dyspnoea, and respiratory function tests showed evidence of pulmonary dysfunction. A third man showed moderate airways obstruction with mild symptoms. On the basis of the results of the investigations on individuals in this study, it is suggested that urinary cadmium concentrations should be kept below $15 \mu \mathrm{g} / \mathrm{day}$ to avoid the possibility of renal damage, and that the insoluble respirable fraction of cadmium dust should not be regarded as merely nuisance dust.
\end{abstract}

Chronic cadmium poisoning is an insidious disease, the principal features of which are pulmonary emphysema and renal damage. The disease develops after prolonged inhalation of cadmium fume or dusts, and it has been suggested that the first sign of the disease may not appear until many years after the last exposure to cadmium. ${ }^{1}$

We describe investigations into the cadmium exposure of employees engaged in manufacturing cadmium selenosulphide and cadmium sulphide pigments in a small factory at Geelong, Victoria. The plant was established in 1952 and is the only such plant in the southern hemisphere. About nine men are employed in the colour production section and about four in the dry colour section. The men in the dry colour section blend colours in small batches $(<50 \mathrm{~kg})$ in well-exhausted blenders, and the cadmium exposure is low. We will not deal with the men working in this section.

In the colour production section cadmium exposure is high in many locations. Flow sheets of the processes used are shown in figs 1 and 2. Cadmium ingots are dissolved in a mixture of nitric and sulphuric acids; cadmium carbonate and cadmium sulphide are produced by precipitation, after which

Received 11 September 1979

Accepted 21 February 1980 the precipitates are filtered and dried. The processes are all wet until this stage and little dust is produced. After drying, the carbonate is crushed, milled, blended with selenium and sulphur, and calcined to produce the red pigment. The cadmium sulphide is also crushed and calcined to produce the yellow pigment. After calcining both pigments are crushed, blended, and milled. All operations after the drying stage are very dusty. Some take only ten minutes whereas others, such as the crushing, take about half of the working period, and the furnace work is almost continuous. It is the custom for the men to move around the factory sharing the different operations. The only exception to this is that two of the men $(G$ and $H)$ have been principally "furnace men" for the past five years. The "furnace man," one for each shift, manually fills the cylindrical calcining tubes $(66 \mathrm{~cm}$ long, $6.5 \mathrm{~cm}$ in diameter) with dry powder, using a spatula. After passing through the furnace, the pigment is knocked out of the tubes by the same man, who is again exposed to a considerable amount of dust.

This investigation will be presented in two parts: (1) an initial assessment of both the working environment and the degree of cadmium absorption of the workmen, started in November 1976, and (2) a follow-up study for a further two-year period. 


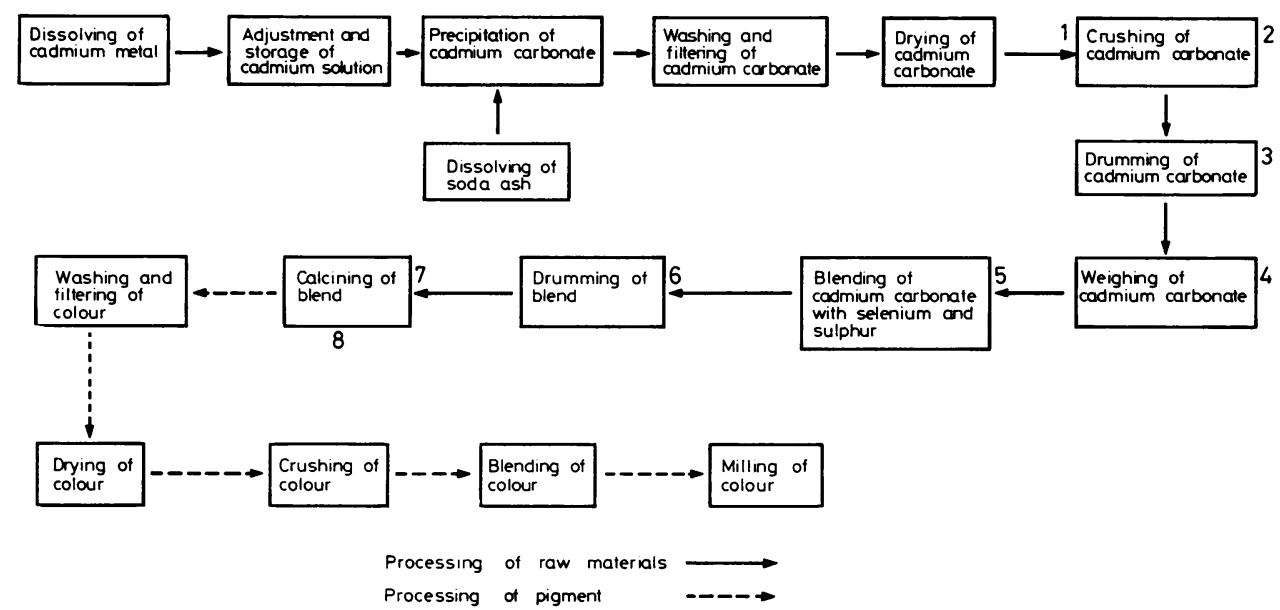

Fig 1 Flow sheet of processes used in cadmium red production. Numbers denote sampling positions

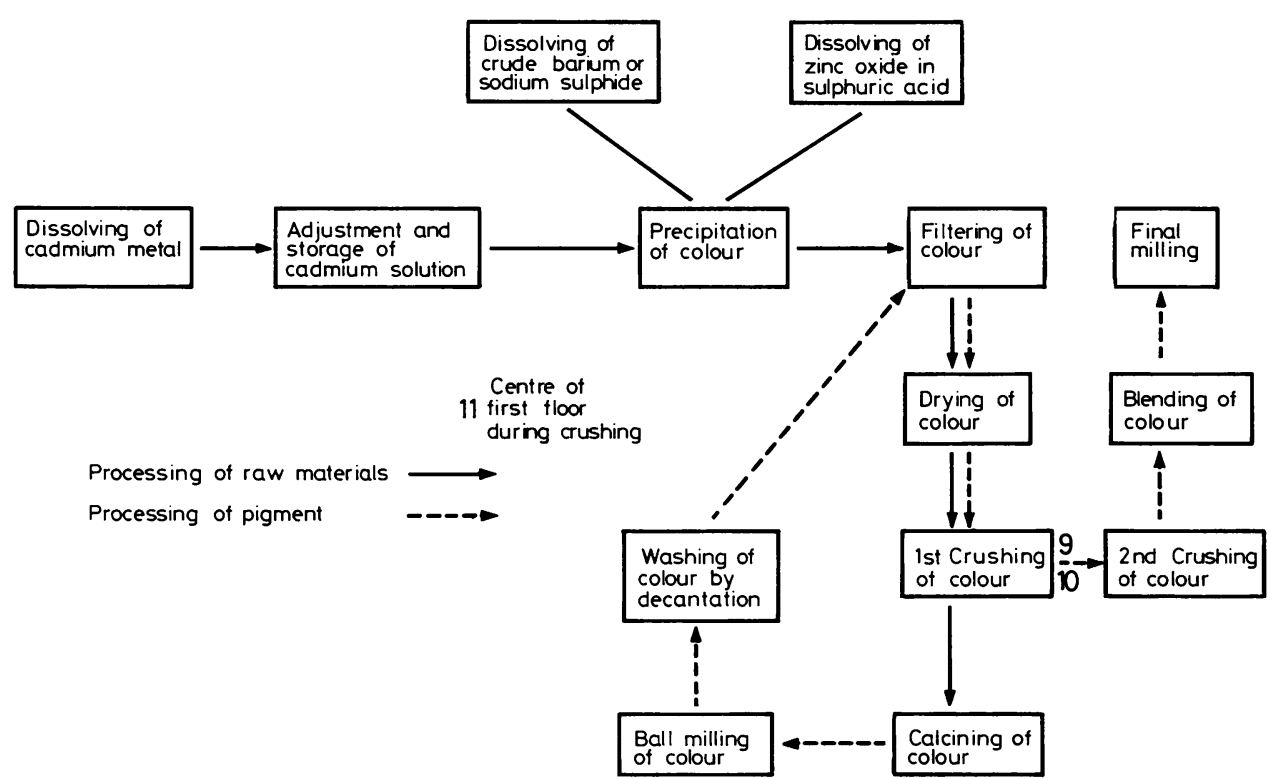

Fig 2 Flow sheet of processes used in cadmium yellow production. Numbers denote sampling positions.

\section{Part I-Initial assessment}

\section{CADMIUM-IN-AIR LEVELS}

Preliminary cadmium-in-air tests were conducted during November 1976. Two different types of dust sampling equipment were used.

(a) Casella personal sampling pumps (flow rate $1.91 / \mathrm{min}$ ) with cyclone sampling heads and membrane filters of pore size $0.8 \mu \mathrm{m}$. The samples collected with this equipment were analysed in two 
Table 1 Cadmium-in-air concentrations measured during November 1976

\begin{tabular}{|c|c|c|c|c|c|c|}
\hline \multirow[t]{2}{*}{ Process } & \multirow[t]{2}{*}{$\begin{array}{l}\text { Position of sampling head } \\
\text { (see figs } 1 \text { and } 2 \text { ) }\end{array}$} & \multirow[t]{2}{*}{$\begin{array}{l}\text { Sampling } \\
\text { equipment } \\
\text { used (see } \\
\text { text) }\end{array}$} & \multirow[t]{2}{*}{$\begin{array}{l}\text { Sampling } \\
\text { time } \\
\text { (min) }\end{array}$} & $\begin{array}{l}\text { Respirable } \\
\text { fraction }\end{array}$ & $\begin{array}{l}\text { Cyclone } \\
\text { fraction }\end{array}$ & $\begin{array}{l}\text { Total } \\
\text { "inhalable" } \\
\text { dust }\end{array}$ \\
\hline & & & & \multicolumn{3}{|l|}{$m g / m^{3}$} \\
\hline Drumming $\mathrm{Cd} \mathrm{CO}_{3}, \mathrm{Se}$, and $\mathrm{S}$ & Breathing zone-position 6 & b & 6 & - & & $4 \cdot 4$ \\
\hline $\begin{array}{l}\text { Adding } \mathrm{Cd}, \mathrm{Se} \text {, and } \mathrm{S} \text { to high speed grinder. } \\
\text { (One-min grinding/drum) }\end{array}$ & Breathing zone -5 & $\mathrm{~b}$ & 26 & 一 & 一 & $1 \cdot 2$ \\
\hline Crushing $\mathrm{Cd} \mathrm{S}$ before calcining & Breathing zone-9 & $\mathrm{b}$ & 22 & 一 & - & 0.90 \\
\hline $\begin{array}{l}\text { General air of } 1 \text { st floor during crushing on ground } \\
\text { floor }\end{array}$ & Centre of first floor -11 & b & 77 & - & $一$ & 0.64 \\
\hline Milling $\mathrm{Cd} \mathrm{CO}_{3}$ & $\begin{array}{l}\text { Fixed position }- \text { on right } \\
\text { hand side of shute }-2\end{array}$ & $\mathrm{~b}$ & 49 & - & 一 & 0.63 \\
\hline Milling $\mathrm{Cd} \mathrm{CO}_{3}$ & $\begin{array}{l}\text { Fixed position-on left } \\
\text { hand side of shute }-1\end{array}$ & b & 64 & - & 一 & $0 \cdot 67$ \\
\hline $\begin{array}{l}\text { Filling } \mathrm{Cd}, \mathrm{Se} \text {, and } \mathrm{S} \text { into calcining tubes, } \\
\text { removing some tubes from furnace, and knocking } \\
\text { out red pigment }\end{array}$ & Breathing zone -7 & a & 97 & $1 \cdot 6$ & $3 \cdot 4$ & $5 \cdot 0$ \\
\hline Drumming milled $\mathrm{Cd} \mathrm{CO}_{3}$ & Fixed position-3 & $\mathbf{b}$ & 14 & - & $一$ & 42 \\
\hline Behind man filling calcining tubes & Fixed position -8 & b & 31 & 一 & - & 0.48 \\
\hline Weighing out milled $\mathrm{Cd} \mathrm{CO}_{3}$ for $\mathrm{Cd}, \mathrm{Se}, \mathrm{S}$ mix & Breathing zone -4 & a & 60 & $2 \cdot 0$ & $2 \cdot 9$ & $4 \cdot 9$ \\
\hline Crushing four racks of yellow pigment & Breathing zone -10 & a & 60 & $1 \cdot 4$ & $6 \cdot 4$ & $7 \cdot 8$ \\
\hline
\end{tabular}

open face pointing down. The same filters were used as for the Casella sampling equipment. The particle size of the samples collected by this equipment was approximately $<7 \mu \mathrm{m}$ (aerodynamic diameter $<20 \mu \mathrm{m})$. The results obtained were perhaps an underestimate of the concentration of total inhalable dust and were therefore not as satisfactory as the results obtained using Casella personal samplers. This equipment, however, was used for most of the initial investigations because it caused less inconvenience to the men, particularly for operations of short duration. For some of the processes shown in table 1, the sampling heads were held in the operator's breathing zone, but for others they were secured in

Table 2 Cadmium-in-air concentrations measured in July 1977

\begin{tabular}{|c|c|c|c|c|c|}
\hline \multirow[t]{2}{*}{ Date } & \multirow[t]{2}{*}{$\begin{array}{l}\text { Main process } \\
\text { for day }\end{array}$} & \multirow[t]{2}{*}{ Time $(h)$} & $\begin{array}{l}\text { Respirable } \\
\text { fraction }\end{array}$ & $\begin{array}{l}\text { Cyclone } \\
\text { fraction }\end{array}$ & $\begin{array}{l}\text { Total } \\
\text { "inhalable" } \\
\text { dust }\end{array}$ \\
\hline & & & \multicolumn{3}{|l|}{$m g / m^{3}$} \\
\hline 7 July & $\begin{array}{l}\text { Furnace work } \\
\text { (red) }\end{array}$ & $6 \cdot 3$ & $1 \cdot 60$ & $2 \cdot 00$ & 3.60 \\
\hline 11 July & , & $4 \cdot 8$ & 0.20 & 0.25 & 0.45 \\
\hline 12 July & ", & $6 \cdot 5$ & $0 \cdot 15$ & $0 \cdot 25$ & 0.40 \\
\hline 13 July & , & $6 \cdot 3$ & 0.55 & $0 \cdot 84$ & $1 \cdot 39$ \\
\hline 14 July & 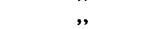 & 6.6 & $1 \cdot 00$ & 0.39 & $1 \cdot 39$ \\
\hline \multicolumn{6}{|c|}{$\begin{array}{l}\text { Furnace work-time- } \\
\text { weighted average } 30.5 \mathrm{~h}\end{array}$} \\
\hline 7 July & $\begin{array}{l}1 \text { average over } 3 \\
\text { Crushing }\end{array}$ & $\begin{array}{c}30 \cdot 5 h \\
6 \cdot 2\end{array}$ & $\begin{array}{l}0.72 \\
0.53\end{array}$ & $\begin{array}{l}0.76 \\
1.42\end{array}$ & $\begin{array}{l}1.48 \\
1.95\end{array}$ \\
\hline 7 July & and & $5 \cdot 8$ & $0 \cdot 16$ & $0 \cdot 38$ & $\begin{array}{l}1.95 \\
0.54\end{array}$ \\
\hline 9 July & cleaning & $5 \cdot 8$ & 0.57 & $0 \cdot 76$ & $1 \cdot 33$ \\
\hline \multicolumn{6}{|c|}{$\begin{array}{l}\text { Crushing and cleaning- } \\
\text { time-weighted average }\end{array}$} \\
\hline over & & $17 \cdot 8 \mathrm{~h}$ & 0.42 & 0.86 & $1 \cdot 28$ \\
\hline 7 July & General & $6 \cdot 4$ & 0.49 & $0 \cdot 20$ & 0.69 \\
\hline 10 July & duties and & $6 \cdot 7$ & 0.98 & $1 \cdot 33$ & $2 \cdot 31$ \\
\hline 2 July & cleaning & 1.9 & $0 \cdot 70$ & 0.49 & $1 \cdot 19$ \\
\hline \multicolumn{2}{|c|}{$\begin{array}{l}\text { General duties-time- } \\
\text { weighted average over }\end{array}$} & $15 \mathrm{~h}$ & $0 \cdot 74$ & 0.74 & $1 \cdot 48$ \\
\hline
\end{tabular}

a fixed position. The latter samples were not intended to estimate the men's exposure but were taken for later assessment of improvements in the factory environment.

The membrane filters were digested in nitric acid, made up to a standard volume, and the cadmium concentration determined by atomic absorption spectrophotometry. The results of the tests are shown in table 1 and the location of the sampling positions in figs 1 and 2 .

The intermittent nature of many of the operations, together with the practice of job rotation makes it difficult to estimate each man's time-weighted average exposure. For five of the processes shown in the table, however, which lasted longer than one hour, the mean cadmium concentration was $3.6 \mathrm{mg} / \mathrm{m}^{3}$ indicating that the time weighted average over eight hours, even without further exposure, would be at least $0.45 \mathrm{mg} / \mathrm{m}^{3}$.

In an attempt to obtain a more accurate picture of the time-weighted average concentration to which these men were exposed, further cadmium-in-air tests were conducted in July 1977. Personal samplers were worn for at least three shifts by each of the men working on the three main processes-furnace work, crushing, and general duties and cleaning. The results (table 2) show all time-weighted average exposures to be greater than $1 \mathrm{mg} / \mathrm{m}^{3}$ with about $50 \%$ of the dust in the respirable range. There was, therefore, little difference in the exposures experienced by men carrying out different duties. The furnace operates almost continuously whereas the other processes are intermittent, thus reducing the exposure of the men doing the general duties, milling, crushing, and cleaning. The furnace operation is usually carried out by the same men ( $G$ and $H)$, 
whose blood cadmium concentrations confirm their heavy exposure.

The concentration of cadmium in the respirable fraction was thus at least ten times higher than the hygiene standard recommended by the British Occupational Hygiene Society Subcommittee on cadmium $\left(0.05 \mathrm{mg} / \mathrm{m}^{3}\right) .^{2}$

\section{CADMIUM IN THE BLOOD AND URINE}

OF WORKERS

Biological testing was started in November 1976. Venous blood samples (each $10 \mathrm{ml}$ ) were collected in heparinised tubes. Urine specimens were 24-hour collections, preserved with sodium azide. Every effort was made to ensure that the men understood the importance of collecting their urine for the entire 24 hours. To avoid contamination from the work environment, however, the specimens were collected during the week-end, and it is probably unrealistic to assume that this was always done properly, particularly when some urine volumes were less than $700 \mathrm{ml}$. The low volumes of F's urines were considered valid, however.

\section{Method}

Blood and urine samples were analysed for cadmium by carbon-rod atomic absorption spectrophotometry after wet ashing and extraction of the cadmium with dithizone followed by back extraction into acid. This method was adopted because the instrument available (Varian AA-1100, with a Varian Carbon Rod Atomizer, Model 63) did not have the facility for simultaneous correction for background absorption. Although this procedure was slow and tedious, careful evaluation showed it to be accurate and precise. Blind recovery studies were carried out on both blood and urine; the mean recovery of cadmium from urine (12 samples) was $81 \%$ and the mean recovery from blood (nine samples) $97 \%$. Blind duplicate analyses were also performed, the correlation coefficient for seven blood specimens being $0.99(a=0.90, b=0.33)$ and for 16 urine specimens, $0.98(a=1 \cdot 1, b=0.06)$. Subsequently, when a new instrument was purchased (Varian AA-175B with Varian CRA-90), the results obtained by our method for cadmium in blood were compared with the results obtained by the simpler method of Brodie and Stevens ${ }^{3}$ which entails direct application of an acid hydrolysate of the blood to the carbon rod. The correlation coefficient between results obtained using the two methods was $0 \cdot 97$, and a regression equation of $\mathrm{Y}=-0.26+1.2 \mathrm{X}$ was derived, where the results obtained by the original method are denoted by X.

In addition to this evaluation of the method, 30 of the 50 blood samples and all 44 urine samples for this study were performed in duplicate, the mean difference between the duplicates for the blood cadmium concentrations being $0.26 \mu \mathrm{g} / 100 \mathrm{ml}$ and for the urinary cadmium concentrations $0.85 \mu \mathrm{g} / \mathrm{l}$.

The range of values obtained in this laboratory for those not occupationally exposed to cadmium are: blood cadmium: $<0 \cdot 2-0 \cdot 6 \mu \mathrm{g} / 100 \mathrm{ml}$, urine cadmium: $<0.5-1.5 \mu \mathrm{g} / \mathrm{l}$.

These normal ranges are in close agreement with the consensus reported by the Commission of the European Communities 4 that,"the normal cadmium concentration in blood appears to be below $1 \mu \mathrm{g} /$ $100 \mathrm{ml}$. . . the amount (of cadmium) excreted daily via the urine is probably below $2 \mu \mathrm{g} /$ day".

The urine was also tested for protein by turbidimetry with trichloracetic acid ${ }^{5}$ using a Lab-trol protein standard (Dade Diagnostics, Inc, Miami, USA). The limit of detection of this method is $0.01 \mathrm{~g} / \mathrm{l}$.

\section{Results}

Table 3 shows the results of the biological tests, which indicate excessive absorption of cadmium in at least five of the men. Two men ( $\mathrm{H}$ and $\mathrm{I})$ were excreting more than $25 \mu \mathrm{g} / \mathrm{l}$ of cadmium, the "threshold value" referred to by Hall et al. ${ }^{6}$ Both these men also had proteinuria, indicating the likelihood of kidney damage. The amount of protein excreted is small and could possibly be regarded as insignificant, particularly in young people. It is notable, however, that proteinuria was present only in the

Table 3 Biological tests on subjects exposed to cadmium-December 1976

\begin{tabular}{|c|c|c|c|c|c|c|c|c|c|}
\hline Subject & $\begin{array}{l}\text { Age } \\
\text { (yr) }\end{array}$ & $\begin{array}{l}\text { Exposure } \\
\text { time }\end{array}$ & $\begin{array}{l}\text { Blood } \\
\text { cadmium } \\
(\mu \mathrm{g} / 100 \mathrm{ml})\end{array}$ & $\begin{array}{l}\text { Urinary } \\
\text { cadmium } \\
(\mu g / l)\end{array}$ & $\begin{array}{l}\text { Urine } \\
\text { SG }\end{array}$ & $\begin{array}{l}\text { 24-hour } \\
\text { urine } \\
\text { vol }(l)\end{array}$ & $\begin{array}{l}\text { Urinary } \\
\text { cadmium } \\
(\mu g / \text { day })\end{array}$ & $\begin{array}{l}\text { Urine } \\
\text { protein } \\
(g / l)\end{array}$ & $\begin{array}{l}\text { Urine } \\
\text { protein } \\
\text { (g/day) }\end{array}$ \\
\hline A & 26 & 7 weeks & $1 \cdot 8$ & $<0.5$ & $1 \cdot 008$ & $1 \cdot 80$ & $<0.9$ & $<0.01$ & - \\
\hline B & 27 & 3 months & 0.6 & $<0.5$ & 1.018 & $1 \cdot 67$ & $<0.8$ & $<0.01$ & 一 \\
\hline C & 37 & 7 months & $2 \cdot 2$ & $<0.5$ & 1.008 & $2 \cdot 65$ & $<1 \cdot 3$ & $<0.01$ & - \\
\hline D & 37 & 9 months & $1 \cdot 1$ & $1 \cdot 5$ & 1.004 & $1 \cdot 37$ & $2 \cdot 0$ & $<0.01$ & 一 \\
\hline E & 58 & 3 years & $3 \cdot 5$ & 11 & $1 \cdot 014$ & 0.72 & $7 \cdot 9$ & $<0.01$ & - \\
\hline$F$ & 35 & 5 years & $1 \cdot 8$ & 18 & $1 \cdot 025$ & 0.70 & 13 & $<0.01$ & - \\
\hline G & 42 & 7 years & $4 \cdot 4$ & 10 & $1 \cdot 009$ & $2 \cdot 15$ & 22 & $<0.01$ & 一 \\
\hline $\mathbf{H}$ & 64 & 13 years & $5 \cdot 4$ & 32 & $1 \cdot 014$ & $1 \cdot 55$ & 50 & 0.09 & 0.14 \\
\hline 1 & 46 & 19 years & $2 \cdot 4$ & 30 & $1 \cdot 021$ & $1 \cdot 32$ & 40 & 0.05 & 0.07 \\
\hline
\end{tabular}


Table 4 Biological tests on subjects previously exposed to cadmium-December 1976

\begin{tabular}{|c|c|c|c|c|c|c|c|c|}
\hline Subject & $\begin{array}{l}\text { Age } \\
(y r)\end{array}$ & $\begin{array}{l}\text { Exposure } \\
\text { time }(y r)\end{array}$ & $\begin{array}{l}\text { Time since } \\
\text { last exposure } \\
(y r)\end{array}$ & $\begin{array}{l}\text { Urinary } \\
\text { cadmium }(\mu g / l)\end{array}$ & $\begin{array}{l}\text { 24-hour } \\
\text { urine } \\
\text { vol }(l)\end{array}$ & $\begin{array}{l}\text { Urinary } \\
\text { cadmium } \\
(\mu g / \text { day })\end{array}$ & $\begin{array}{l}\text { Urine protein } \\
(g / l)\end{array}$ & $\begin{array}{l}\text { Urine } \\
\text { protein } \\
\text { (g/day) }\end{array}$ \\
\hline $\begin{array}{l}\mathbf{J} \\
\mathbf{K} \\
\mathbf{L}\end{array}$ & $\begin{array}{l}47 \\
66 \\
38\end{array}$ & $\begin{array}{r}14 \\
11 \\
8\end{array}$ & $\begin{array}{l}10 \\
1 \cdot 5 \\
1 \cdot 5\end{array}$ & $\begin{array}{l}8 \cdot 0 \\
19 \\
\text { (i) } 24 \\
\text { (12-13 Dec } 76) \\
\text { (ii) } 19 \\
\text { (12-13 May 77) }\end{array}$ & $\begin{array}{l}1 \cdot 77 \\
1 \cdot 79 \\
1 \cdot 60 \\
1 \cdot 50\end{array}$ & $\begin{array}{l}14 \\
37 \\
38 \\
\\
29\end{array}$ & $\begin{array}{l}0.03 \\
0.71 \\
\text { No test } \\
0.12\end{array}$ & $\begin{array}{l}0.05 \\
1 \cdot 3 \\
- \\
0 \cdot 19\end{array}$ \\
\hline
\end{tabular}

two subjects excreting more than $25 \mu \mathrm{g} / \mathrm{l}$ of cadmium.

Urinary cadmium and protein tests were also carried out on three other men, two past employees and the manager of the factory. The latter had started the manufacturing process in 1952 but had been engaged in office work since about 1966. The results indicated that urinary cadmium concentrations were still raised many years after exposure had ceased, and in all cases proteinuria was present (table 4).

One of the past employees (K) had been investigated for cadmium poisoning in 1974 and had been found to have a blood cadmium concentration of $7 \cdot 3 \mu \mathrm{g} / 100 \mathrm{ml}$ at the end of 11 years' exposure.

KIDNEY FUNCTION TESTS

Further investigation into renal function was con- sidered advisable in those subjects with proteinuria, and also in subject $\mathrm{G}$ who was excreting $22 \mu \mathrm{g}$ $\mathrm{Cd} /$ day. Table 5 shows the results of ${ }^{125}$ I iothalamate clearance tests and tests for concentration and acidification ability performed at a Melbourne hospital. The five subjects tested were present employees $G$, $\mathrm{H}$, and $\mathbf{I}$, the manager $\mathbf{J}$, and past employee $\mathbf{L}$. All except I showed a defect in concentrating ability consistent with papillary damage. With damage at this site, a co-existent defect in acidification was also expected, but tests failed to confirm this. All subjects, including $\mathrm{I}$, failed to attain a urinary $\mathrm{pH}$ of less than 5 ; in no case, however, did the plasma $\mathrm{CO}_{2}$ concentration fall after administration of ammonium chloride. Subject $\mathrm{G}$ is of special interest because he showed a defect in concentrating ability in the absence of proteinuria, an indication that damage

Table 5 Renal function of those with raised cadmium excretion

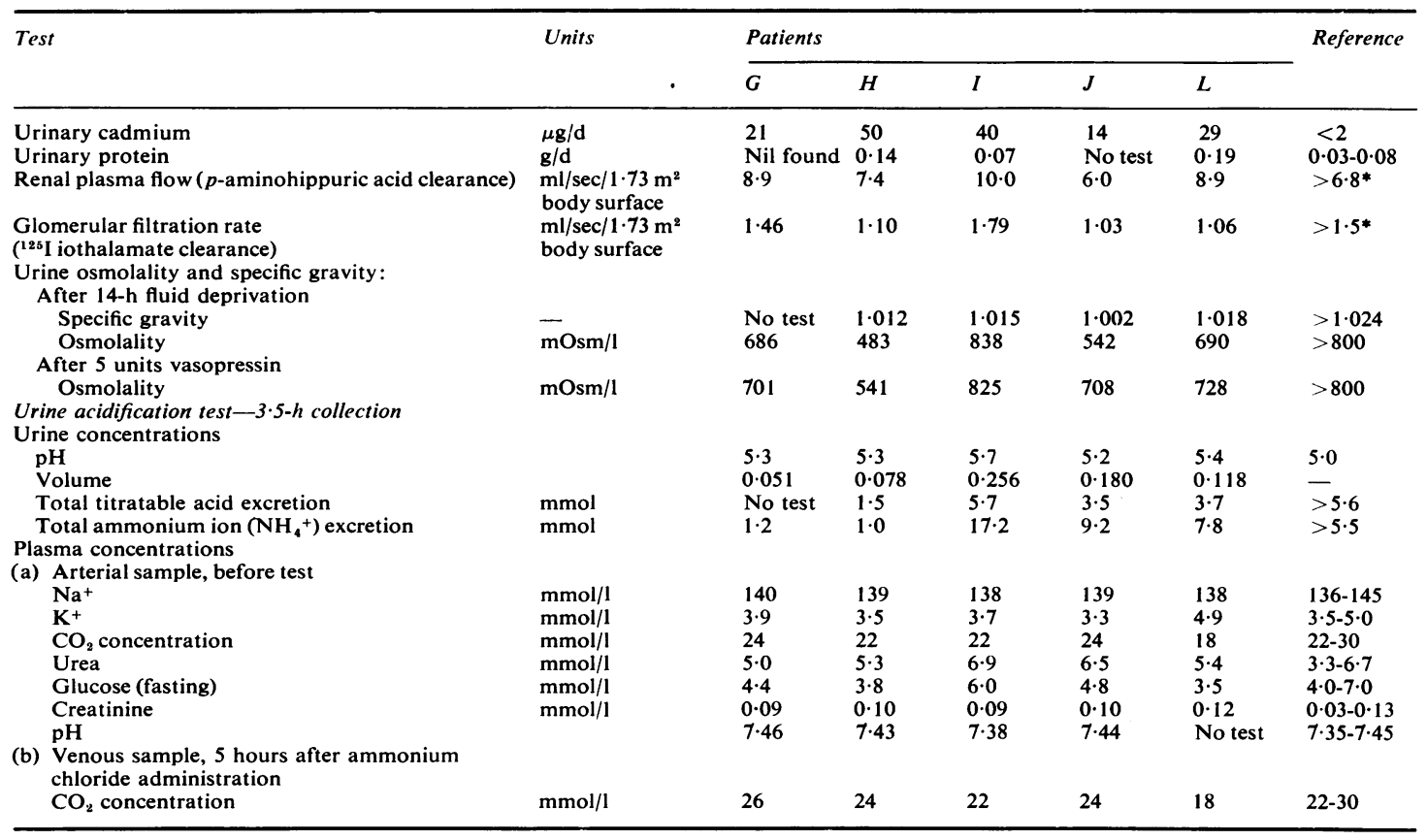

* Lower limits of renal plasma flow and glomerular filtration rate have been adjusted for age of subjects. 
Table 6 Respiratory function tests

\begin{tabular}{|c|c|c|c|c|c|c|c|c|c|}
\hline Subject & $\begin{array}{l}\text { Age } \\
(y r)\end{array}$ & $\begin{array}{l}\text { Cigarette } \\
\text { smoking } \\
\text { history (packs } \\
\text { of 20/day } \times \\
\text { yr smoking) }\end{array}$ & $\begin{array}{l}\text { Vital } \\
\text { capacity } \\
(V C)\end{array}$ & $\begin{array}{l}\text { Predicted } \\
V C\end{array}$ & $\begin{array}{l}\% \text { of } \\
\text { predicted } \\
V C\end{array}$ & $F E V_{1}$ & $\begin{array}{l}\text { Predicted } \\
F E V_{1}\end{array}$ & $\begin{array}{l}\% \text { of } \\
\text { predicted } \\
F E V_{1}\end{array}$ & $\frac{F E V_{1}}{V C}$ \\
\hline $\begin{array}{l}\text { A } \\
B \\
D \\
\text { E } \\
\text { F } \\
\text { G } \\
\text { H } \\
\text { I }\end{array}$ & $\begin{array}{l}26 \\
27 \\
37 \\
58 \\
35 \\
42 \\
64 \\
46\end{array}$ & $\begin{array}{r}11 \\
11 \\
16 \\
2 \\
16 \\
22 \\
50 \\
24\end{array}$ & $\begin{array}{l}4 \cdot 3 \\
6 \cdot 2 \\
4 \cdot 2 \\
4 \cdot 2 \\
6 \cdot 1 \\
4 \cdot 2 \\
1 \cdot 9 \\
3 \cdot 5\end{array}$ & $\begin{array}{l}4 \cdot 0 \\
5 \cdot 6 \\
4 \cdot 7 \\
4 \cdot 1 \\
5 \cdot 3 \\
5 \cdot 0 \\
3 \cdot 7 \\
3 \cdot 4\end{array}$ & $\begin{array}{r}>100 \\
>100 \\
90 \\
>100 \\
>100 \\
83 \\
51 \\
>100\end{array}$ & $\begin{array}{l}3 \cdot 6 \\
4 \cdot 7 \\
3 \cdot 3 \\
2 \cdot 6 \\
4 \cdot 4 \\
1 \cdot 6 \\
0 \cdot 6 \\
2 \cdot 8\end{array}$ & $\begin{array}{l}3 \cdot 5 \\
4 \cdot 3 \\
3 \cdot 7 \\
3 \cdot 1 \\
4 \cdot 2 \\
3 \cdot 9 \\
2 \cdot 9 \\
2 \cdot 8\end{array}$ & $\begin{array}{r}>100 \\
>100 \\
87 \\
84 \\
>100 \\
41 \\
21 \\
>100\end{array}$ & $\begin{array}{l}83 \\
76 \\
76 \\
62 \\
72 \\
38 \\
32 \\
80\end{array}$ \\
\hline $\begin{array}{l}\mathbf{J} \\
\mathbf{L}\end{array}$ & $\begin{array}{l}47 \\
38\end{array}$ & $-\frac{}{3}$ & $\begin{array}{l}5 \cdot 2 \\
4 \cdot 1\end{array}$ & $\begin{array}{l}4 \cdot 4 \\
4 \cdot 0\end{array}$ & $\begin{array}{l}>100 \\
>100\end{array}$ & $\begin{array}{l}4 \cdot 2 \\
2 \cdot 7\end{array}$ & $\begin{array}{l}3 \cdot 4 \\
3 \cdot 3\end{array}$ & $\begin{array}{r}>100 \\
82\end{array}$ & $\begin{array}{l}79 \\
66\end{array}$ \\
\hline
\end{tabular}

may occur first in the papillae.

\section{RESPIRATORY FUNCTION TESTS}

Using a bellows spirometer (Vitalograph), vital capacity and forced expiratory volume in one second $\left(F E V_{1}\right)$ were measured for all the workmen. The results, shown together with details of age and smoking history, indicate severe airways obstruction in two of the men ( $\mathrm{H}$ and $\mathrm{G}$ ) and mild airways obstruction in two others ( $E$ and $L)$ (table 6). Clinical histories were obtained at this time, but they have since been updated and are reported in the follow-up study.

More detailed respiratory function tests were carried out on the men on whom detailed renal function tests had been performed. These tests confirmed the severe airways obstruction in subjects $\mathbf{H}$ and $\mathrm{G}$, with high lung volumes and low carbon monoxide transfer consistent with emphysema. L showed moderate airways obstruction with normal lung volumes. Although two of these men ( $\mathrm{G}$ and $\mathrm{H}$ ) were fairly heavy smokers, it appears that their respiratory function was more severely affected than could be explained by their smoking history. Subject $\mathrm{L}$ was a very light smoker.

\section{SUMMARY OF INITIAL ASSESSMENT}

Six cases of chronic cadmium poisoning had occurred in this plant, three present employees, the manager and two past employees; these six men being all those who had worked there for at least seven years.

Two of the present employees ( $\mathrm{H}$ and $\mathrm{I}$ ) were excreting more than $40 \mu \mathrm{g} /$ day of cadmium, had protein in their urine, and impaired ability to acidify and concentrate urine. One of the men $(H)$ had severe emphysema with symptoms. The third employee (G) was excreting $22 \mu \mathrm{g} /$ day of cadmium in urine and although no protein was present, there was evidence of damage to kidney tubules. His respiratory function tests showed moderately severe emphysema. He was 42 and had been employed by this firm for seven years. The manager of the firm (J) had been almost completely unexposed to cadmium for the past ten years. Nevertheless, his cadmium excretion was still $14 \mu \mathrm{g} /$ day and he had proteinuria and decreased ability to acidify and concentrate urine. One of the past employees (K) had been investigated for cadmium poisoning in 1974, and his clinical history is included in the follow-up section. The other past employee $(L)$ had a mild defect in concentration and acidification of urine, and moderate airways obstruction.

\section{Part II-Follow-up study of exposed workers}

Biological monitoring of all men, including new employees and those in the dry colour section, has been continued. Two groups are of particular interest; old employees who were removed from exposure after the initial assessment, and new employees who were first tested within 12 months of starting work in the plant.

Immediately after the initial assessment $\mathbf{H}$ was retired and has had no further exposure, while I, F, and $\mathrm{G}$ were given work outside the colour production section, and their exposure has since been insignificant. E, who always spent about half his time outside the factory building tending the dissolving of the ingots, has remained in the same job but has worn an air-supplied respirator when working inside the factory. The results obtained on these men, together with the manager $\mathbf{J}$, are shown in table 7 .

It is concluded that urinary cadmium concentrations remain raised for many years after the blood cadmium concentration has returned to normal.

The results obtained on the 11 new employees (table 8) fall into two categories, for those who had worked for less than three months and for those who had worked for longer periods. The interpretation of these results will be developed in the discussion 
Table 7 Follow-up-original subjects

\begin{tabular}{|c|c|c|c|c|c|c|c|c|c|c|}
\hline \multirow[t]{2}{*}{ Subject } & \multirow{2}{*}{$\begin{array}{l}\text { Date of } \\
\text { cessation } \\
\text { of exposure }\end{array}$} & \multicolumn{3}{|c|}{$\begin{array}{l}\text { Blood cadmium } \\
(\mu \mathrm{g} / 100 \mathrm{ml})\end{array}$} & \multicolumn{3}{|c|}{$\begin{array}{l}\text { Urinary cadmium } \\
(\mu g / l)\end{array}$} & \multicolumn{3}{|c|}{$\begin{array}{l}\text { Urinary cadmium } \\
(\mu g / \text { day })\end{array}$} \\
\hline & & $\begin{array}{l}\text { Dec } \\
1976\end{array}$ & $\begin{array}{l}\text { Dec } \\
1977\end{array}$ & $\begin{array}{l}\text { Dec } \\
1978\end{array}$ & $\begin{array}{l}\text { Dec } \\
1976\end{array}$ & $\begin{array}{l}\text { Dec } \\
1977\end{array}$ & $\begin{array}{l}\text { Dec } \\
1978\end{array}$ & $\begin{array}{l}\text { Dec } \\
1976\end{array}$ & $\begin{array}{l}\text { Dec } \\
1977\end{array}$ & $\begin{array}{l}\text { Dec } \\
1978\end{array}$ \\
\hline $\mathbf{H}$ & Dec 76 & $5 \cdot 4$ & $3 \cdot 0$ & $2 \cdot 5$ & 32 & 14 & 10 & 50 & 17 & 22 \\
\hline G & Dec 76 & $4 \cdot 4$ & $2 \cdot 0$ & 1.8 & 10 & $4 \cdot 2$ & $7 \cdot 3$ & 22 & 11 & 15 \\
\hline$F$ & Dec 76 & $1 \cdot 8$ & $1 \cdot 2$ & 0.9 & 18 & 16 & 19 & 13 & 16 & 11 \\
\hline $\mathrm{E}^{*}$ & - & $3 \cdot 5$ & $1 \cdot \overline{8}$ & $1 \cdot 7$ & 11 & $6 \cdot 2$ & 21 & $7 \cdot 9$ & 13 & 30 \\
\hline I & Dec 76 & $2 \cdot 4$ & $2 \cdot 1$ & 0.8 & 30 & 15 & 15 & 40 & 22 & 26 \\
\hline $\mathbf{J}$ & 1966 & - & 0.6 & 0.6 & $8 \cdot 0$ & $7 \cdot 4$ & $7 \cdot 0$ & 14 & 10 & 10 \\
\hline
\end{tabular}

*Air-supplied respirator used since December 1976.

section.

In January 1980 all cases were clinically reviewed with the following findings:

\section{Subject K (raw blend operator)}

This Yugoslavian speaks little English, and the following history was obtained through an interpreter. He was born in 1911 and started smoking about 20 cigarettes a day at the age of 14 . He came to Australia in 1951 and started working at the plant in 1963 when aged 52, and worked almost entirely on the raw blend of cadmium carbonate, selenium, and sulphur (positions 5 and 6 in fig 1), where his exposure to cadmium was very high. This job entailed much walking up and down stairs as the mixer was on the first floor and the blend was drummed on the ground floor. For a few months before June 1974 he had had to stop every 12 or so steps for a "puff and a rest." At about this time he also developed a cough with sputum; it was not possible, however, to ascertain whether the cough developed before or after the dyspnoea. He had not had a cough before despite his heavy smoking.

In June 1974 he was admitted to hospital with acute bronchitis and was diagnosed as having chronic cadmium poisoning. He was discharged after ten days and at this stage reduced his smoking considerably. He returned to work but could do only light duties until he retired in January 1975. At this time his appetite was poor, he vomited daily, and had lost about $6 \mathrm{~kg}$ in weight. By December 1977 his shortness of breath had considerably increased and in conversation he stopped every few words for breath. In January 1980 he was severely short of breath and was suffering from occasional severe coughing spasms with sputum that lasted until he vomited. Apart from these attacks he has had little stomach trouble in the past 18 months.

\section{Subject $H$ (furnace man)}

This man started work at the firm in 1963 when aged 51 . He started smoking about 20 cigarettes a day when aged 15. In December 1975 he noticed short- ness of breath at work and was unable to continue lifting. By December 1976 he was very short of breath even when walking on level ground but had no chronic cough or sputum. In March 1977 he had an attack of bronchitis and pleurisy; otherwise cough and sputum have been absent. After this illness he gave up smoking and retired from work. In January 1980 his shortness of breath was severe but no worse than it was in December 1976.

\section{Subject $G$ (furnace man)}

This man started work at the firm in 1969 at the age of 35 . He began to smoke about 20 cigarettes a day when he was 20. In December 1976 he could do heavy lifting and walk upstairs without difficulty. In January 1977, after the first biological tests, he was moved to work outside the plant. At this stage he had not noticed any shortness of breath but the work outside was much easier, with no climbing stairs or heavy lifting. When interviewed in January 1980 he stated that since May 1977 he had had a morning cough with sputum and shortness of breath, which was relieved when the phlegm was coughed up. $\mathrm{He}$ did not do any heavy work and did not know how he could cope with his old job.

\section{Subject E (general duties)}

This man started work with the firm in 1972 at the age of 54 . He started smoking when 38 but smoked

\section{Table 8 Follow-up-new employees}

\begin{tabular}{|c|c|c|c|c|}
\hline \multirow[t]{2}{*}{ Subject } & \multirow{2}{*}{$\begin{array}{l}\text { Exposure time } \\
\text { (months) }\end{array}$} & \multirow{2}{*}{$\begin{array}{l}\text { Blood cadmium } \\
(\mu \mathrm{g} / 100 \mathrm{ml})\end{array}$} & \multicolumn{2}{|c|}{ Urinary cadmium } \\
\hline & & & $(\mu g / l)$ & $(\mu g /$ day $)$ \\
\hline $\mathbf{M}$ & 1.8 & 1.8 & $<0.5$ & $<0.9$ \\
\hline $\mathbf{N}$ & 3 & 0.6 & $<0.5$ & $<0.8$ \\
\hline $\mathrm{O}$ & 3 & 0.9 & 1.0 & $2 \cdot 1$ \\
\hline $\mathbf{P}$ & 5 & 1.4 & $1 \cdot 7$ & 3.9 \\
\hline $\mathbf{Q}$ & 6 & $2 \cdot 4$ & $5 \cdot 1$ & $2 \cdot 9$ \\
\hline $\mathbf{R}$ & 6 & 0.7 & $1 \cdot 3$ & 1.6 \\
\hline S & 7 & 1.7 & $2 \cdot 6$ & $2 \cdot 0$ \\
\hline$T$ & 7 & $2 \cdot 2$ & $<0.5$ & $<1.3$ \\
\hline $\mathbf{U}$ & 8 & 1.0 & $5 \cdot 5$ & $5 \cdot 4$ \\
\hline V & 9 & $2 \cdot 1$ & $6 \cdot 1$ & $8 \cdot 5$ \\
\hline W & 12 & $1 \cdot 1$ & $1 \cdot 5$ & $2 \cdot 0$ \\
\hline
\end{tabular}


only about 20 cigarettes a week for eight years and then changed to smoking a pipe occasionally. In February 1977 and in May 1979 he had attacks of bronchitis with cough and sputum lasting a few days and now does not smoke at all. He had no exertional dyspnoea.

Subjects $I, J$, and $L$

None of these men had clinical symptoms.

\section{Discussion}

INTERPRETATION OF BIOLOGICAL INDICES In the CEC monograph ${ }^{4}$ the working group of experts make several observations relating to the importance of biological indices in studying cadmium absorption. They tentatively suggest that, "cadmium in blood is probably not a reflection of body burden but is mainly influenced by current exposure." On the other hand, they indicate that "whether cadmium in urine reflects the body burden or current exposure is still debatable" and proceed to summarise the evidence supporting each argument. The results of this study indicate that neither the blood cadmium nor the urinary cadmium concentrations reflects "current exposure" in the sense of recent exposure over weeks or months.

The blood cadmium concentration rises soon after exposure begins (table 8) and falls when it ends (table 7) by about half in the first year but much more slowly from then on. This suggests that the blood-cadmium concentration reflects the concentration in a substantial reservoir in the body, which we shall refer to as the extra-renal store, presumably consisting of several compartments with half-lives varying from about one year (in blood) to about five years (in other soft tissues).

The results also indicate that the urinary cadmium concentration rises and falls with exposure, probably with a delay of several months (table 8). Raised concentrations, decades after exposure has ceased, indicate that urinary cadmium reflects the concentration in another substantial reservoir in the body with a half life of decades. It is suggested that this reservoir is the renal as distinct from the extra-renal store.

When exposure ends the proportionate fall in urinary cadmium in the first year is much the same as in the blood cadmium (table 7). By the end of the second year, however, with no further exposure, the blood cadmium continues to fall, although much more slowly, while the urinary cadmium remains high. This suggests that the urinary cadmium content has a contribution from both reservoirs in the body.

The best indication of the degree of "current exposure" would be given by the cadmium content in the compartment with the shortest half-life. In the absence of a better index blood cadmium concentrations give a reasonable measure of degree of exposure, but only after a period of two or three years.

A knowledge of the individual's work history is therefore important in the interpretation of either index. Three of our workers who were exposed for under three months (table 8) showed raised cadmium concentrations in the blood but not in the urine. Workers exposed for more than five months all showed raised blood concentrations and six of the eight showed raised urine concentrations. We infer that for the first three months the blood cadmium concentration indicated that exposure to cadmium was occurring. The absorbed cadmium, however, was retained in the body and not excreted.

Regression analyses were carried out on the results from the original nine men (table 3 ), and the correlation coefficients obtained between differing variables give support to the above hypotheses.

\begin{tabular}{lllc}
\hline Variable $X$ & Variable $Y$ & $\begin{array}{l}\text { Correlation } \\
\text { coefficient }\end{array}$ & $p$ value \\
\hline Years of working & $\begin{array}{l}\text { Urinary cadmium }(\mu \mathrm{g} / \mathrm{day}) \\
\text { Yrinary cadmium }(\mu \mathrm{g} / \mathrm{l})\end{array}$ & 0.93 & $<0.92$ \\
$\begin{array}{l}\text { Years of working } \\
\text { Years of working }\end{array}$ & $\begin{array}{l}\text { Blood cadmium } \\
(\mu \mathrm{g} / 100 \mathrm{ml})\end{array}$ & 0.44 & 0.001 \\
$\begin{array}{l}\text { Blood cadmium } \\
(\mu \mathrm{g} / 100 \mathrm{ml})\end{array}$ & Urinary cadmium $(\mu \mathrm{g} / \mathrm{l})$ & 0.61 & 0.08 \\
\hline
\end{tabular}

There is a high correlation between years of working and urinary cadmium, confirming that urinary cadmium concentrations are a good indication of the accumulation of cadmium in the body.

Blood cadmium concentrations do not correlate well with years of exposure or with urinary cadmium. From the subject's work history they appear to correlate reasonably well with degree of exposure to cadmium over several years.

The results obtained in this study indicate that, in workers currently exposed to cadmium, kidney damage may occur at a urinary cadmium concentration below that suggested by Lauwerys $e^{2} a^{8}$ as a "safe" concentration-namely, $15 \mu \mathrm{g} / \mathrm{g}$ creatinine (about $30 \mu \mathrm{g} / \mathrm{day}$ ). We suggest that concentrations above $15 \mu \mathrm{g} /$ day be regarded as unacceptably high.

In the case of people with past exposure to cadmium, urinary cadmium concentrations below $15 \mu \mathrm{g} /$ day do not indicate freedom from kidney damage. In these cases protein in the urine is a good indication of the need for further detailed kidney function tests to be performed. The pronounced rise in urinary cadmium concentration of subject $\mathrm{E}$ as his blood cadmium continues to fall cannot be explained by the long half life of cadmium in the kidney but may 
Table 9 Dose-effect relations

\begin{tabular}{|c|c|c|c|c|c|c|}
\hline \multirow[t]{2}{*}{ Subject } & \multicolumn{2}{|c|}{$\begin{array}{l}\text { Estimated weekly average } \\
\text { exposure levels }\left(\mathrm{mg} / \mathrm{m}^{3}\right)\end{array}$} & \multirow{2}{*}{$\begin{array}{l}\text { Exposure } \\
\text { time } \\
(y r)\end{array}$} & \multirow{2}{*}{$\begin{array}{l}\text { Blood } \\
\text { cadmium } \\
(\mu \mathrm{g} / 100 \mathrm{ml})\end{array}$} & \multirow[t]{2}{*}{ Symptoms } & \multirow[t]{2}{*}{ Signs } \\
\hline & $\begin{array}{l}\text { Respirable } \\
\text { dust }\end{array}$ & $\begin{array}{l}\text { Total } \\
\text { dust }\end{array}$ & & & & \\
\hline $\mathbf{K}$ & $\begin{array}{l}\text { No separate } \\
\text { analysis of } \\
\text { respirable } \\
\text { fraction }\end{array}$ & 2 & 11 & $7 \cdot 3$ & $\begin{array}{l}\text { Dyspnoea }++. \text { In } \\
\text { hospital for acute } \\
\text { bronchitis. Vomiting, } \\
\text { cough, sputum }\end{array}$ & $\begin{array}{l}\text { Moderate airways obstruction. } \\
\text { Proteinuria }++ \text {. Renal damage }\end{array}$ \\
\hline $\mathbf{H}$ & 0.7 & $1 \cdot 5$ & 13 & $5 \cdot 4$ & $\begin{array}{l}\text { Dyspnoea }++ \text {. No } \\
\text { chronic cough or sputum }\end{array}$ & Severe airways obstruction \\
\hline $\mathbf{G}$ & 0.7 & $1 \cdot 5$ & 7 & $4 \cdot 4$ & $\begin{array}{l}\text { Dyspnoea }+. \text { Chronic } \\
\text { cough, sputum }\end{array}$ & $\begin{array}{l}\text { Severe airways obstruction. No } \\
\text { proteinuria. Renal tubular damage }\end{array}$ \\
\hline $\mathbf{E}$ & $0 \cdot 3$ & 0.7 & 3 & $3 \cdot 5$ & $\begin{array}{l}\text { No dyspnoea. Two } \\
\text { attacks bronchitis }\end{array}$ & $\begin{array}{l}\text { Mild airways obstruction. No } \\
\text { proteinuria. Renal tubular damage }\end{array}$ \\
\hline $\mathbf{F}$ & 0.3 & 0.7 & 5 & $1 \cdot 8$ & No symptoms & $\begin{array}{l}\text { Intermittent proteinuria. No } \\
\text { respiratory abnormality }\end{array}$ \\
\hline I & $0 \cdot 3$ & 0.7 & 19 & $2 \cdot 4$ & No symptoms & $\begin{array}{l}\text { No respiratory abnormality. } \\
\text { Proteinuria-slight. No defect in } \\
\text { concentration, possible defect in } \\
\text { acidification }\end{array}$ \\
\hline
\end{tabular}

be indicative of the onset of renal damage. At the time of writing, renal function tests have just been performed on this subject and also on subject $F$, who has recently begun to show protein in his urine. The renal function tests indicated that subject $E$ has decreased ability to concentrate urine but normal urine acidification. Subject $F$ has normal renal function.

\section{DOSE-EFFECT RELATIONS}

The practice of job rotation, the intermittent nature of many of the processes, and the frequently high concentration of cadmium in the general factory air make it difficult to differentiate between each man's level of exposure with any degree of accuracy. The only significantly different exposure within the original group of nine men working at the time of the initial assessment was that of the furnace men who were at their job almost continuously, whereas the other men worked on dusty jobs for only about half of their week. The furnace men therefore had about double the exposure of the other men, and this is confirmed by their higher blood cadmium concentrations.

The past employee $\mathrm{K}$ had worked almost continuously on the raw blend using a milling machine that had ceased to be used by the time the first air tests were conducted. According to the men, this was the dustiest job of all. Levels obtained on the present milling machine indicate that his exposure must have been very high, of the order of $2 \mathrm{mg} / \mathrm{m}^{3}$ (positions 5 and 6 in fig 1 and table 1).

The men could, therefore, be divided roughly into three groups according to their estimated weekly average exposure: the raw blend operator $\mathrm{K}$ (total dust about $2 \mathrm{mg} / \mathrm{m}^{3}$ ), the furnace men $\mathrm{H}$ and $\mathrm{G}$ (total dust about $1.5 \mathrm{mg} / \mathrm{m}^{3}$ ), and the others engaged in general duties with dusty work occupying about half their time (total dust about $0.7 \mathrm{mg} / \mathrm{m}^{3}$ ). Of the three men most heavily exposed $(\mathrm{K}, \mathrm{H}$, and $\mathrm{G})$, the results of $G$ indicate that at this level of exposure, respiratory damage with clinical symptoms and renal tubular damage not associated with symptoms occurred after only seven years.

None of the men with lower exposure showed symptoms in December 1976, although E showed mild airways obstruction. In August 1979, however, renal function tests showed that $\mathrm{E}$ had decreased ability to concentrate urine, although no protein was detected. Subject F showed normal renal function but intermittent proteinuria. Exposures at this level for three to five years have, therefore, resulted in signs of cadmium poisoning not associated with clinical symptoms.

Blood cadmium determinations if carried out while a worker is still exposed to cadmium give a reasonable estimate of degree of exposure after about two years. Table 9 shows the relation between exposure levels, blood cadmium concentrations, and signs and symptoms for the six workers still exposed to cadmium when the blood cadmium was determined.

TOXICITY OF INSOLUBLE CADMIUM Over the years the management of the firm considered that only soluble cadmium salts were toxic. 
Notices warning of the toxicity of cadmium carbonate were displayed in locations where it was handled, and employees were encouraged to wear "nuisance" dust masks at these locations. No precautions at all were taken during the crushing and milling of the "insoluble" cadmium pigments. This was understandable because as recently as the 1973 edition of Threshold Limit Values for Chemical Substances and Physical Agents in the Workroom Environment ${ }^{9}$ the entry for cadmium was "metal dust and soluble salts, $0 \cdot 2 \mathrm{mg} / \mathrm{m}^{3}$."

The extent to which the insoluble cadmium pigments contributed to these cases of poisoning and to those of Kazantzis $e t$ al $^{10}$ is uncertain in view of the presence of cadmium carbonate. Possibly there was sufficient cadmium carbonate alone to account for these cases of poisoning.

Comparison of the exposure levels and blood cadmium concentrations shown in table 9 with those obtained by Lauwerys ${ }^{8}$ for 27 workers (exposed for a mean of nine years to a respirable dust concentration of about $0.09 \mathrm{mg} / \mathrm{m}^{3}$, mean blood cadmium concentration $3 \mu \mathrm{g} / 100 \mathrm{ml}$ ) suggests that the insoluble respirable cadmium compounds are less able to enter the blood stream than the soluble compounds. This possibility is supported by the case reported by Kazantzis et al, ${ }^{10}$ which came to necropsy and showed an extremely high concentration of cadmium in the lung compared with other published figures from cases of chronic cadmium poisoning due to soluble cadmium. Respirable insoluble compounds probably contribute significantly to the lung damage, and there is therefore ample reason for not differentiating between soluble and insoluble respirable cadmium.

The question of the toxicity of the non-respirable insoluble fraction is important in that this fraction is regarded as "nuisance" dust by the British Occupational Hygiene Society Subcommittee on Cadmium. ${ }^{11}$ This opinion is apparently based on unpublished data on a pigment factory, from which they conclude, "that had the absorption of the insoluble nonrespirable' fraction been remotely similar to, say, the 'soluble respirable dust', the biochemical data would have been vastly different." The subcommittee then makes an analogy with lead and uses the Pottery (Health) Special Regulations 1947 as a precedent for dividing an element into its soluble and insoluble compounds. It is pointed out that the Harwell studies $^{12}$ have shown that the absorption of soluble and insoluble compounds of lead from the gut is significantly different only when a person is fasting. The lower biological indices of absorption obtained after exposure to insoluble compounds of cadmium may be due to a reduced ability of the respirable fraction to enter the blood stream rather than to the reduced solubility of the non-respirable fraction in the gut. It could perhaps be concluded that nonrespirable insoluble compounds may be slightly less hazardous than soluble compounds; but to regard them as merely nuisance dust is not only risky but also liable to misinterpretation and to encourage carelessness in their use.

The conditions in the factory are under urgent review. A complete revision of the manufacturing process has been necessary to reduce the cadmium concentration in the air to an acceptable level. Initial simple improvements and stringent housekeeping measures have reduced the time-weighted average concentration of the cadmium dust by roughly one half. Nevertheless, until the firm implements the extensive improvements necessary to reduce the cadmium concentration in air to a "safe" level, workers are wearing air supplied respirators.

We are indebted to the staff of the renal unit and the respiratory unit of the Repatriation General Hospital, Heidelberg, for the performance of the renal function tests and the detailed respiratory function tests. We particularly appreciate the help given by Dr W Adam (RGHH) and Dr D Goddard (Industrial Hygiene Section) in the interpretation of the renal function tests. This paper is published with the consent of the Health Commission of Victoria.

\section{References}

${ }^{1}$ Bonnell JA. Cadmium poisoning. Ann Occup Hyg 1965;8: 45-50.

${ }^{2}$ British Occupational Hygiene Society Committee on Hygiene Standards: Subcommittee on Cadmium. Hygiene standard for cadmium. Ann Occup Hyg 1977;20:215-28.

${ }^{3}$ Brodie KG, Stevens BJ. Measurement of whole blood lead and cadmium at low levels using an automatic sample dispenser and furnace atomic absorption. Journal of Analytical Toxicology 1977;1:282-5.

4 Commission of the European Communities. Criteria (dose/ effect relationships) for cadmium. 1st ed. Oxford: Pergamon Press, 1978:50-62.

${ }^{5}$ Henry RJ. In: Henry RJ, Cannon DC, Winkelman JW, eds. Clinical chemistry. 2nd ed. Hagerstown, Md: Harper and Row, 1974:430-1.

- Hall SA, Harrington JM, Newhouse ML. In: Schilling RSF, ed. Occupational health practice. 1st ed. London: Butterworth, 1973:107-8.

${ }^{7}$ Meerkin M, Clarke R, Oliphant R. Chronic cadmium poisoning. Med J Aust 1976;1:23-4.

${ }^{8}$ Lauwerys RR, Buchet JP, Roels HA, Brouwers J, Stanescu D. Epidemiological survey of workers exposed to cadmium. Arch Environ Health 1974;28:145-8.

'American Conference of Government Industrial Hygienists. Threshold limit values for chemical substances and physical agents in the workroom environment. Cincinnati: ACGIH, 1973.

${ }^{10}$ Kazantzis G, Flynn FV, Spowage JS, Trott DG. Renal 
tubular malfunction and pulmonary emphysema in cadmium pigment workers. $Q J$ Med 1963;32:165-92.

11 British Occupational Hygiene Society Standards Subcommittee on Cadmium. Ann Occup Hyg 1978;21 :408-12.
12 Chamberlain AC, Heard MJ, Little P, Newton D, Wells $\mathrm{AC}$, Wiffen RD. Investigations into lead from motor vehicles. Harwell: United Kingdom Atomic Energy Authority, HMSO, 1978.

\section{The November 1980 issue}

\section{THE NOVEMBER 1980 ISSUE CONTAINS THE FOLLOWING PAPERS}

Epoxides-is there a human health problem? MARGARET M MANSON

Deposition, retention, and clearance of inhaled particles M LIPPMANN, D B YEATES, AND R E ALBERT

Observations on the lungs of vanadium workers M KIVILUOTO

Pulmonary disease from occupational exposure to an artificial aluminium silicate used for cat litter A W MUSK, H W GREVILLE, AND A E TRIBE

Retention of vinyl chloride in the human lung J KRAJEWSKI, M DOBECKI, AND J GROMIEC

Scanning electron microscopy and $x$-ray microanalysis of mineral deposits in lungs of a patient with pleural mesothelioma E M OPHUS, G MOWÉ, K K OSEN, AND B GYLSETH

Effects of chronic ethanol consumption on hepatic metabolism of aromatic and chlorinated hydrocarbons in rats A SATO, T NAKAJIMA, AND Y KOYAMA

Copies are still available and may be obtained from the PUBLISHING MANAGER, BRITISH MEDICAL ASSOCIATION, TAVISTOCK SQUARE, LONDON WC1H 9JR, price $£ 4.25$ (USA $\$ 9.20$ ), including postage

the of chronic carbon disulphide intoxication on the development of experimental atherosclerosis in rats TERESA WRONSKA-NOFER, S SZENDZIKOWSKI, AND MARIA OBREBSKA-PARKE

Placental and stillbirth tissue lead concentrations in occupationally exposed women A K KHERA, D G WIBBERLEY, AND J G DATHAN

Leptospira hebdomadis associated with an outbreak of illness in workers on a farm in North Yorkshire $S$ M CRAWFORD AND D W MILES

Role of family susceptibility, occupational and family histories and individuals' blood groups in the development of silicosis M H NOWEIR, M MOSELHI, AND E K AMINE

Notes and miscellanea

Effects of exposure to slate dust in North Wales A JONES

Book reviews

Notice

Information section 